\title{
Peranan Penggunaan Transportasi Publik di Perkotaan (Studi Kasus Penggunaan Kereta Commuterline Indonesia Rute Jakarta-Bekasi)
}

\author{
Hendra Wijayanto ${ }^{1}$ \\ Universitas 17 Agustus Jakarta \\ Email: hendra.pelajar@gmail.com
}

\begin{abstract}
Public transport is an important means of development for life. The importance of transportation is reflected in the increasing need for transportation services for human mobility and goods as a result of the increasing population growth and the development of settlements in big cities. One type of transportation that can be used as an alternative to overcome the problems of public transportation needs above is the train. Trains that are a means of transportation with many advantages such as low pollution, free of traffic, bulk, cheaper cost, and also save time.With the various advantages possessed by the train above, is expected to be a consideration in order to become an increasingly complex solution of transportation problems in urban areas.
\end{abstract}

Keywords: Role, Public Transport, KRL

\begin{abstract}
Abstrak; Transportasi Publik merupakan sarana perkembangan yang penting bagi kehidupan. Pentingnya transportasi tersebut tercermin pada semakin meningkatnya kebutuhan akan jasa angkutan bagi mobilitas manusia serta barang sebagai akibat meningkatnya perkembangan penduduk dan perkembangan pemukiman di kota-kota besar.Salah satu jenis transportasi yang dapat dijadikan alternatif untuk mengatasi permasalahan kebutuhan transportasi publik di atas adalah kereta api. Kereta api yang merupakan alat transportasi dengan banyak keunggulan seperti rendah polusi, bebas macet, bersifat massal, biaya lebih murah, dan juga menghemat waktu. Dengan berbagai keunggulan yang dimiliki oleh kereta api di atas, diharapkan dapat dijadikan bahan pertimbangan guna menjadi solusi permasalahan transportasi di perkotaan yang semakin kompleks.
\end{abstract}

Kata Kunci: Peranan, Transportasi Publik, KRL 


\section{Pendahuluan}

Transportasi Publik merupakan sarana perkembangan yang penting bagi kehidupan. Pentingnya transportasi tersebut tercermin pada semakin meningkatnya kebutuhan akan jasa angkutan bagi mobilitas manusia serta barang sebagai akibat meningkatnya perkembangan penduduk dan perkembangan pemukiman di kota-kota besar. Salah satu jenis transportasi yang dapat dijadikan alternatif untuk mengatasi permasalahan kebutuhan transportasi publik di atas adalah kereta api. Kereta api yang merupakan alat transportasi dengan banyak keunggulan seperti rendah polusi, bebas macet, bersifat massal, biaya lebih murah, dan juga menghemat waktu.

Dengan berbagai keunggulan yang dimiliki oleh kereta api di atas, diharapkan dapat dijadikan bahan pertimbangan guna menjadi solusi permasalahan transportasi di perkotaan yang semakin kompleks. BUMN yang mengelola transportasi darat khususnya kereta api adalah PT Kereta Api (Persero) sebagai badan penyelenggara tunggal jasa angkutan kereta api di Indonesia yang membentuk anak perusahaan bernama PT Kereta Commuter Indonesia (PT KCI) yang berfungsi sebagai penyelenggara jasa angktan kereta api di daerah Jabodetabek.

PT Kereta Commuter Indonesia adalah salah satu anak perusahaan di lingkungan PT Kereta Api Indonesia (Persero) yang mengelola Kereta Commuterline Indonesia (KCI) dan sekitarnya. KCI dibentuk sesuai dengan Inpres No. 5 tahun 2008 dan Surat Menteri Negara BUMN No. S-653/MBU/2008 tanggal 12 Agustus 2008. Pembentukan anak perusahaan ini berawal dari keinginan para stakeholdernya untuk lebih fokus dalam memberikan pelayanan yang berkualitas dan menjadi bagian dari solusi masalah transportasi perkotaan yang semakin kompleks.

Berdasarkan pengamatan penulis masyarakat Jabodetabek khususnya di wilayah Jakarta sampai Bekasi alat transportasi kereta listrik commuterline merupakan solusi percepatan aktivitas yang marak digunakan, umumnya untuk melakukan aktivitas seperti bekerja, rekreasi dan kuliah, dengan menggunakan kereta listrik commuterline tujuannya untuk menempuh waktu yang cepat dan tepat serta hemat biaya karena tiket kereta terbilang murah menjadi solusi dari bebas kemacetan di jalan raya, bebas polusi, dan menikmati fasilitas yang nyaman.

Namun demikian penulis melihat kendala yang sering terjadi atas keterlambatan kereta commuterline yang datang tidak sesuai tepat waktu oprasional nya, keresahan ini sudah biasa terjadi pada masyarakat khusunya di rute stasiun KCI Jakarta-Bekasi. keterlambatan yang terjadi biasa nya di akibatkan oleh dua masalah yaitu pertama ialah overcapacity pada penumpang KCI yang masuk di hari kerja biasanya terjadi pada hari senin-jumat pukul 07.00-09.00 WIB dan waktu pulang kerja yaitu sekitar pukul 17.00-19.30 WIB kereta mengalami delay karena banyak nya penumpang yang naik, mengakibatkan pintu kereta menjadi terbuka lebih lama dan antrian tiket KCI menjadi ramai.

Permasalahan yang kedua ialah masalah infrastruktur kereta, menurut pengamatan penulis selain akibat penumpang yang overcapacity, 
permasalahan infrasturktur menjadi penyebab lain yang menghambat kereta commuterline di stasiun KCI Jakarta-Bekasi yang menjadi terlambat tiba di stasiun. Penulis melihat peristiwa yang terjadi di rute KCI Jakarta-Bekasi yaitu rusaknya rel kereta commuterline yang diakibatkan oleh rel yang memuai terkena suhu panas, dan pernah terjadi kereta commuterline keluar dari jalur rel akibat kesalahan sistem.

Sesuai prinsip Good Governance yaitu efektivitas dan efisien dalam melayani masyarakat, Pemerintah seharus nya menciptakan sarana publik khususnya sarana transportasi umum yang memudahkan masyarakatnya untuk beraktivitas di dalam sebuah Negara, untuk mengukur apakah sebuah negara itu di lihat sebagai Negara yang berkembang kedepan.

Dengan melihat kedua permasalahan diatas penulis melakukan penelitian karena ingin membuktikan dengan adanya PT Kereta Commuterline Indonesia (KCI) merupakan perusahaan yang bergerak di bidang jasa pelayanan umum angkutan darat, apakah sudah efektif dan efisien dalam implementasiannya pada masyarakat, karena masih di temui beberapa gangguan yang menjadi permasalahan yang menghambat aktivitas manusia.

Pesatnya pertumbuhan penduduk dan perkembangan pemukiman memicu tingginya mobilitas manusia dalam beraktivitas sehingga perkembangan teknologi transportasi publik berbasis rel yang mampu menjangkau masyarakat dari pinggir kota menuju pusat kota. Meskipun bertempat tinggal jauh, mereka tetap mampu menjangkau pusat kota dengan adanya Kereta Commuter Line (KCI) di area Jabodetabek khusus nya Rute JakartaBekasi guna untuk mempermudah aktivitas manusia dalam menjalani kehidupan. Akan tetapi masih di temui sejumlah permasalahan yang membuat Penerapan pengguna Kereta Commuter Line Indonesia (KCI) di Rute Jakarta-Bekasi menjadi terhambat. Melihat Rumusan masalah diatas menghasilkan pertanyaan penelitian, yaitu : "Bagaimanakah peranan penggunaan trasnportasi publik Kereta Commuterline Indonesia di rute JakartaBekasi ?"

\section{Metode Penelitian}

Metode penelitian yang dipakai oleh peneliti adalah metode Implementasi dan studi kasusnya penggunaan Kereta Commuterline Indonesia (KCI) di Jabodetabek Rute Jakarta-Bekasi penulis melakukan penelitian ini karena ingin membuktikan dengan adanya PT Kereta Commuterline Indonesia (KCI) merupakan perusahaan yang bergerak di bidang jasa pelayanan umum angkutan darat, apakah sudah efektif dan efisien dalam penerapan pelayanannya pada masyarakat. Dalam penelitian ini, peneliti menggunakan key informan seperti Karyawan atau Humas PT. KAI Commuter Line Indonesia. Key informan ini memberikan informasi yang berhubungan dengan pengmplementasi penggunaan Kereta Commuterline Indonesia (KCI) di Jabodetabek Rute Jakarta-Bekasi selama bulan oktobernovember tahun 2017 dan juga peneliti membutuhkan informan seperti penumpang kantoran dan mahasiswa sebagai sub informan atas penerapan kinerja oprasi Kereta Commuterline 
Indonesia. Untuk memperoleh data yang dibutuhkan, peneliti menggunakan tekhnik pengumpulan data yang dilakukan dengan beberapa cara, yaitu melalui data primer dan data sekunder.

\section{Pembahasan}

Berdasarkan pengamatan penulis masyarakat Jabodetabek khususnya di wilayah Jakarta sampai Bekasi alat transportasi kereta listrik commuterline merupakan solusi percepatan aktivitas yang marak digunakan, umumnya untuk melakukan aktivitas seperti bekerja, rekreasi dan kuliah, dengan menggunakan kereta listrik commuterline tujuannya untuk menempuh waktu yang cepat dan tepat serta hemat biaya, karena tiket kereta terbilang murah menjadi solusi dari bebas kemacetan di jalan raya, bebas polusi, dan menikmati fasilitas yang nyaman.

Namun demikian penulis melihat kendala yang sering terjadi atas keterlambatan kereta commuterline yang datang tidak sesuai tepat waktu oprasional nya, keresahan ini sudah biasa terjadi pada masyarakat khusunya di rute stasiun KCI Jakarta-Bekasi rute Kranji-Manggarai-DuriGrogol. keterlambatan yang terjadi biasa nya di akibatkan oleh dua masalah yaitu pertama ialah overcapacity pada penumpang KCI yang masuk di hari kerja biasanya terjadi pada hari senin-jumat pukul 07.00-09.00 WIB dan waktu pulang kerja yaitu sekitar pukul 17.00-19.30 WIB kereta mengalami delay karena banyak nya penumpang yang naik, mengakibatkan pintu kereta menjadi terbuka lebih lama dan antrian tiket KCI menjadi ramai.

Permasalahan yang kedua ialah masalah infrastruktur kereta, menurut pengamatan penulis selain akibat penumpang yang overcapacity, permasalahan infrasturktur menjadi penyebab lain yang menghambat kereta commuterline di stasiun KCI Jakarta-Bekasi yang menjadi terlambat tiba di stasiun. Penulis melihat peristiwa yang terjadi di rute KCI Jakarta-Bekasi yaitu rusaknya rel kereta commuterline yang diakibatkan oleh rel yang memuai terkena suhu panas, dan pernah terjadi kereta commuterline keluar dari jalur rel akibat kesalahan sistem.

Maka dengan demikian untuk mempermudah mobilitas manusia dalam menggunakan KRL pihak PT.KCI mensosialisasikan beberapa cara dalam melakukan pembayaran tiket serta efektivitas pengguna KRL, antara lain dengan menyediakan beberapa kartu EMoney seperti kartu Flazz Bca dan Kartu Tiket Berjamin Harian untuk membayar dengan cepat dalam proses mobilitas masyarakat pengguna KRL, kemudian ada beberapa karakter dalam penggunaan kedua kartu tersebut. informasi diatas bisa di dapat di tempat stasiun KRL.

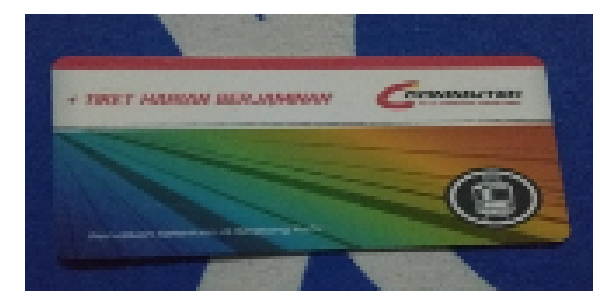

Gambar 1.

Pertama Kartu Tiket Harian Berjamin KRL Sumber: Koleksi Pribadi

Gambar 1. merupakan tiket resmi dari PT. KCI sebagai alat pembayaran regular yang dapat di beli di loket stasiun KRL di seluruh Jabodetabek. jenis kartu ini sebagai bentuk saldo dalam satu 
perjalanan jika harus transit di beberapa stasiun dan beralih ke kereta lain, tetapi jika dalam satu rute yang sejalur rel, kartu tersebut memiliki keistimewaan single trip yaitu, bisa digunakan untuk berangkatkembali. menurut pengamatan peneliti kartu ini kurang efektif dan efisien dalam menjalankan mobilitas yang tinggi sebab dibutuhkan pengisian ulang di loket stasiun pada saat transit dan harus keluar dari pintu masuk KRL. tetapi bagi yang tidak mengetahui pembayaran tiket KRL menggunakan kartu E-Money dianjurkan untuk awal menggunakan kartu ini.

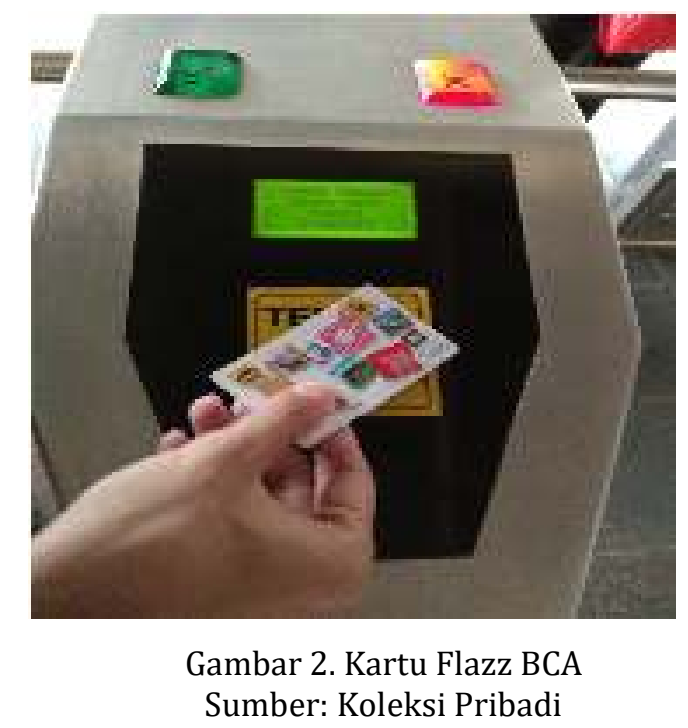

Kemudian jika pengguna KRL baru dan tidak begitu paham dengan mobiltas KRL ke stasiun tujuan, penggunaan dapat mendownload di AppStore atau Google Play di Handphone IOS dan Android anda masing-masing, pada intinya di aplikasi tersebut dijelaskan jadwal datang dan berangkat KRL dan banyak informasi tentang KRL lain nya. berikut ialah gambar bentuk aplikasi KRL indonesia di Handphone Android dan IOS :

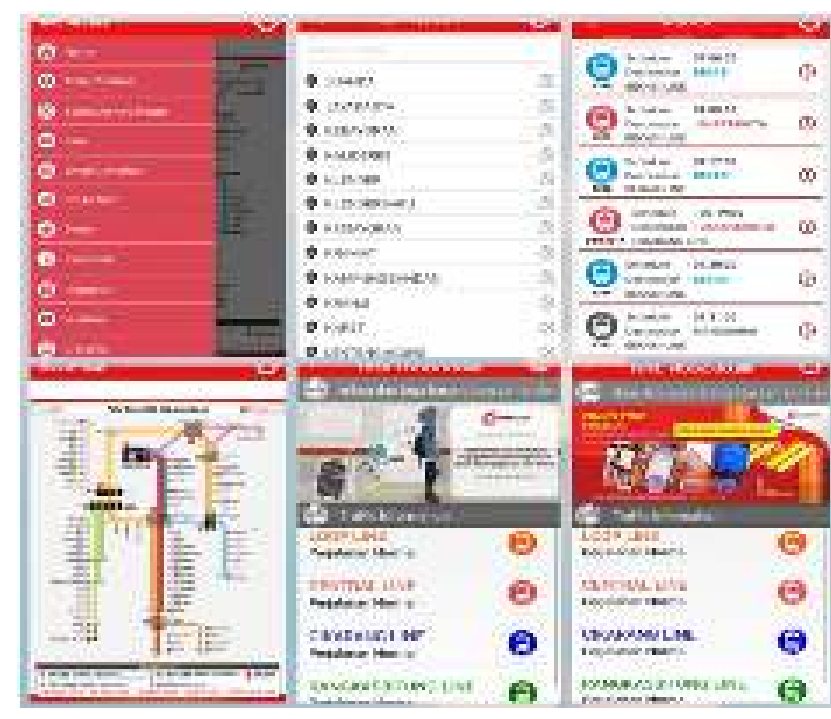

Gambar 3. Tampilan Aplikasi KRL pada Android dan IOS.

Sumber: Pribadi

Pada gambar 3. merupakan bentuk dari gambar aplikasi KRL Jabodetabek di ponsel Android maupun IOS, dengan aplikasi ini pengguna setia KRL sejabodetabek dapat memudahkan akses menaiki kereta apa yang di tuju ke sebuah tujuan stasiun dan tanpa harus menanyakan pada petugas stasiun di sekitar rel KRL. cara ini merupakan solusi efektif dalam mempermudah mobilitas pengguna setia KRL dalam bekerja maupun kuliah, serta mempersingkat waktu tanpa harus menanyakan pada petugas, karena terkadang petugas KRL yang di sekitaran stasiun rel KRL sibuk bertugas.

Pada gambar pertama merupakan pilihan menu untuk mengakses fitur-fitur tertentu pada aplikasi KRL Jabodetabek, bagian pilihan menu tersaji beberapa menu pilihan antara lain ialah posisi KRL,home aplikasi,Email untuk komplain,jadwal keberangkatan kereta dan menu media sosial seperti Twitter,Istagram,Facebook 
dan Youtube untuk melihat perkembangan informasi KRL berada dimana.

Hal ini juga dapat mengetahui update terkini seputar KRL dan juga menghindari dari keterlambatan kereta yang akan datang. dengan aplikasi KRL Jabodetabek ini pihak PT.KCI sudah secara langsung terbuka kepada masyarakat umum, dengan ini pembuktian bahwa pelayanan KRL yang berbasis milik negara atau BUMN, pemerintah dan swasta sudah bekerja sama dengan khalayakumum memperluas jaringan informasi dan sarana yang sangat efektif dan efisien sesuai prinsip Good Governance.

Pada temuan di lapangan perilaku masyarakat dalam penggunaan KRL di stasiun Kranji mengalami kenaikan tinggi jumlah penumpang, dikarenakan peneliti melihat keadaan disaat minggu kerja di hari jumat pagi pukul 09.00 WIB keadaan disana sangat ramai namun tertib. kemudian pada rute berikutnya di stasiun Manggarai pukul 10.00 WIB peneliti menemukan keadaan stasiun yang sangat terlihat mobilitas nya tinggi, tetapi peneliti menemukan dan mewawancarai beberapa penumpang KRL yaitu seorang Karyawan dan seorang Pelajar / Mahasiswa setelah di wawancarai, peneliti berhasil menemukan bahwa mayoritas pengguna KRL usia muda antara 20-30 tahun, sudah tahu tentang cara menggunakan KRL secara efektif dan efisien melalui aplikasi KRL Jabodetabek di Android atau IOS.

Perubahan Zaman dimana semua serba Elektronik dan instan memudahkan mobilitas tinggi kehidupan manusia di era global saat ini, semua informasi mengenai KRL mudah di dapat dan diterapkan secara bertahap akan tetapi menurut peneliti
Infrastruktur pada KRL dalam tahap pembangunan dan peneliti yakin dalam beberpa tahun kedepan negara Indonesia dapat unggul di asia tenggara dalam transportasi massal yang terkhususkan yaitu Kereta Commuterline. pemerintah dan swasta saat ini sudah berupaya mengmaksimalkan segala aspek tentang pembangunan dan tata cara manajamen penggunaan KRL dengan tepat. tetapi jika di sosialisasikan dengan baik pasti semua kalangan dapat menikmati kegunaan KRL dengan mudah tepat dan nyaman sesuai pada prinsip yang ingin di wujudkan Pemerintah oleh Prinsip Good Governance yaitu Efektif dan Efisien.

Asia tenggara dalam transportasi massal yang terkhususkan yaitu Kereta Commuterline. pemerintah dan swasta saat ini sudah berupaya mengmaksimalkan segala aspek tentang pembangunan dan tata cara manajamen penggunaan KRL dengan tepat. tetapi jika di sosialisasikan dengan baik pasti semua kalangan dapat menikmati kegunaan KRL dengan mudah tepat dan nyaman sesuai pada prinsip yang ingin di wujudkan Pemerintah oleh Prinsip Good Governance yaitu Efektif dan Efisien.

Dengan melihat keadaan di lapangan maka peneliti dapat memberikan analisa pada penelitian ini. sejauh temuan peneliti, penerapan penggunakan KRL sudah sangat baik yang di peran kan oleh masyarakat tetapi disisi lain masih di temui beberapa sedikit permasalahan yang agak rumit dalam mempergunakan aplikasi elektronik. humas dari PT. KCI Andri Setyo Nugroho sudah memaparkan bentuk dari berbagai pelayanan kartu KRL dan keistimewaan nya masing-masing tetapi menurutnya masyarakat lah yang harus 
cerdas dalam meraih informasi tentang penggunaan KRL sebelum menaiki nya karena sejauh ini pihak PT.KCI sudah terbuka Informasi atau transparansi mengenai KRL sejabodetabek dan sudah disosialisasikan di seluruh media sosial saat ini.

Menurut peneliti untuk penggunaan KRL kepada Lansia agak sulit karena dengan kecanggihan yang berbasis kekinian saat ini rata-rata sulit untuk memahami penggunaan nya, tetapi disaat banyak petugas di sekitaran rel yang dapat memberikan informasi secara jelas. untuk sejauh ini menurut peneliti jenis transportasi massa KRL ini masih sangat populer dikalangan khalayak umum masih banyak penggunanya untuk mempermudah mobilitas aktivitas mereka, rata-rata pengguna nya yaitu mahasiswa dan pekerja kantoran.

\section{Kesimpulan}

Berdasarkan hasil penelitian yang telah peneliti lakukan, maka dapat di tarik kesimpulan sebagai berikut : dalam penelitian ini yang berjudul Peranan Penggunaan Transportasi Publik di Perkotaan (Studi kasus penggunaan Kereta Commuterline Indonesia (KCI) di Rute Jakarta-Bekasi) dalam penelitian ini peneliti menggunakan teori prinsip Good Governance yaitu efektif dan efisen terhadap pelayanan umum.

Pada penelitian ini obyek utama ialah pernan pengguna KRL yaitu masyarakat, dengan cara mengukur dengan teori Good Governance sebagai alat penelitian, disini peneliti di posisikan sebagai pengguna dan pengamat pengunaan KRL Jabodetabek. Dengan melihat keadaan di lapangan maka peneliti dapat memberikan analisa pada penelitian ini. sejauh temuan peneliti, penerapan penggunakan KRL sudah sangat baik yang di peran kan oleh masyarakat tetapi disisi lain masih di temui beberapa sedikit permasalahan yang agak rumit dalam mempergunakan aplikasi elektronik.

Perubahan Zaman dimana semua serba Elektronik dan instan memudahkan mobilitas tinggi kehidupan manusia di era global saat ini, semua informasi mengenai KRL mudah di dapat dan diterapkan secara bertahap akan tetapi menurut peneliti Infrastruktur pada KRL dalam tahap pembangunan dan peneliti yakin dalam beberpa tahun kedepan Negara Indonesia dapat unggul di asia tenggara dalam transportasi massal yang terkhususkan yaitu Kereta Commuterline.

Pemerintah dan swasta saat ini sudah berupaya mengmaksimalkan segala aspek tentang pembangunan dan tata cara manajamen penggunaan KRL dengan tepat. tetapi jika di sosialisasikan dengan baik pasti semua kalangan dapat menikmati kegunaan KRL dengan mudah tepat dan nyaman sesuai pada prinsip yang ingin di wujudkan Pemerintah oleh Prinsip Good Governance yaitu Efektif dan Efisien.

\section{Daftar Pustaka}

Keban, T. Yeremias. 2004. Enam Dimensi Strategis Administrasi Publik Konsep, Teori, dan Isu. Jakarta: Gava Media.

Hansen. 2017. Journal of Rail Transport Planning \& Management (Affiliated with the International Association of Railway Operations Research) Delft University of technology ,Delft, Netherlands. 
Indah Wahyu Maesarini, Rizky Ramadan

Fauzi. 2016. Analisis Tingkat

Kepuasan Pelanggan KRL Sistem

Commuterline (Studi kasus pada PT

Kereta Api Commuterline

Jabodetabek) Administrasi Publik, STIAMI Jakarta.

Inpres No. 5 tahun 2008 dan Surat Menteri

Negara BUMN No. S-653/MBU/2008 tanggal 12 Agustus 2008.

Sugandi, Yogi. Suprayogi. 2011.Administrasi Publik Konsep dan Perkembangan Ilmu di Indonesia. Jakarta.

Undang - Undang Dasar Negara Republik Indonesia Tahun 1945. 